\title{
Badania i konserwacja zabytkowej ceramiki szkliwionej w rzeźbie i detalu architektonicznym
}

\section{Wstęp}

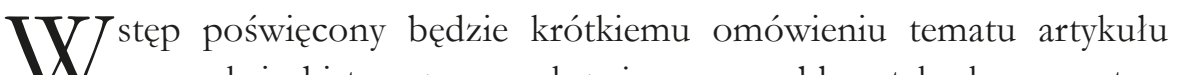
w aspekcie historycznym, ukazującemu problematykę konserwatorską dotyczącą kształtowania się i stopniowego rozpoznawania zagadnień konserwacji i restauracji zabytkowej ceramiki i szkła, zanalizowana w oparciu o zdobyte doświadczenia praktyczne (w trakcie prowadzenia zabiegów konserwatorskich) oraz badania własne i wypracowane przez lata na zajęciach ze studentami, a także w ramach prowadzonych prac magisterskich od początku funkcjonowania Zakładu Konserwacji Elementów i Detali Architektonicznych. Początkowo prace konserwatorskie przy zabytkach odbywały się w ramach zajęć w Pracowni Konserwatorskiej, a następnie Pracowni Dyplomowej (od lat 90. XX w.).

Autorka artykułu od lat 70. XX w. prowadzi działalność konserwatorską m.in. w zakresie konserwacji i restauracji ceramiki artystycznej i użytkowej oraz zajmuje się badaniami technologicznymi i materiałoznawczymi zabytkowych materiałów porowatych i nieporowatych, takich jak podłoża ceramiczne oraz warstwy dekoracji szkliwnej.

Od 1975 roku kieruje konserwatorskimi pracami końcowymi i dyplomowymi studentów specjalności KRzKiDA, w tym także przy cennych za- 
bytkach ceramicznych oraz tych wykonanych ze szkła. Wykonuje kopie zabytkowej ceramiki w technologii konserwatorskiej - bez wypalania. Opracowała technologię postępowania konserwatorskiego przy zabezpieczaniu, uzupełnianiu ubytków i rekonstrukcjach malarskich w zabytkowych obiektach ceramicznych, w tym także archeologicznych ${ }^{1}$.

Znaczacym dorobkiem badawczym oraz konserwatorskim autorki artykułu było opracowanie metody konserwacji i restauracji renesansowych kafli Wielkiego Pieca (1545) z Dworu Artusa w Gdańsku oraz ich kompleksowa rewaloryzacja przeprowadzona w latach 1984-1991. Celem prac było odtworzenie bryły - zniszczonego w czasie II wojny światowej - zabytkowego pieca poprzez montaż kafli metodą „suchą” (bez użycia wody), w pierwotnym miejscu jego posadowienia. Prace zostały udokumentowane opisowo, graficznie i fotograficznie osobno dla każdego kafla, a także opublikowane ${ }^{2}$.

Zdobyte doświadczenie zawodowe pozwoliło na rozszerzenie problematyki konserwatorsko-restauratorskiej na specjalności Konserwacja Rzeźby Kamiennej i Detali Architektonicznych o zagadnienia związane z technologia, zniszczeniami oraz konserwacja zabytkowej ceramiki artystycznej i użytkowej. W efekcie od 1992 roku autorka przygotowała nowy tematu wykładów dla studentów ww. specjalności, pt. „Naturalne i sztuczne kamienie w rzeźbie i architekturze - ceramika”, który do dziś prowadzi.

W ramach konserwatorskich prac własnych oraz dyplomowych opracowała: technologię mas do uzupełniania zabytkowej ceramiki i szkliw w oparciu o nowe spoiwa i technologie malarskie, włączając je na stałe do programów konserwatorskich i programów nauczania ${ }^{3}$. Przykłady innowa-

1 M. Rudy, Ksqtatcenie studentów w zakeresie konserwacji ceramiki artystycznej, „Ochrona Zabytków", nr 2, 1995, s. 212-219; eadem, Amfora cypryjska i Pelike czerwono figurowa - zagadnienia technologiczne $i$ konserwatorskie antycznej ceramiki archeologicznej, „Ochrona Zabytków” nr 2, 1999, s. 141-152; eadem, Uzupetnianie ubytków i rekonstrukcje w ceramice artystycznej i usiytkowej, „Studia i Materiały Wydziału Konserwacji i Restauracji Dzieł Sztuki ASP w Krakowie”, IX. cz. II 2000.

2 M. Rudy, Zniszczenia i konserwacja renesansonych kafli Wielkiego Pieca z. Dworu Artusa w Gdańsku, „Ochrona Zabytków”, nr 3, 1996, s. 251-260; eadem, Conservation of Renaissance tiles from the Grand Stove In Gdansk. Arthus' Court, 8-th International Congress on Deterioration and Conservation of Stone, Berlin 1996.

3 M. Rudy, P. Niemcewicz, Konserwacja zabytkón ceramicznych sztuki Dalekiego Wschodu w Zaktadzie Konserwacij Elementów i Detali Architektonicznych Instytutu Zabytkoznawstwa i Konserwator- 
cyjnych rozwiązań w doborze materiałów i metod stosowanych w trakcie zabiegów zaprezentowano w kierowanych przez autorkę pracach konserwatorskich IV i V roku w Pracowni Konserwatorskiej w latach 80. oraz w Pracowni Dyplomowej w latach 1991-1996, opisanych w dokumentacjach konserwatorskich ${ }^{4}$.

W XXI wieku nowością było zastosowanie zmodyfikowanych farb żywicznych - konserwatorskich Maimeri do imitacji barwnych szkliw na zabytkowym licowym kaflu piecowym oraz zastosowanie farb Marabu i Decor Lack Marabu GmbH do imitacji barwnych szkliw na uzupełnieniach w zabytkowych obiektach porcelanowych ${ }^{5}$. Odnotować należy także opracowanie

stwa WSP UMK Torun, „Toruńskie Studia o Sztuce Orientu”, t. 3, 2008, s. 53; M. Rudy, Methods and Materials Used in Filling Losses in Ceramic Historic Objects, 11-th International Congress on Deterioration and Conservation of Stone, Torun 2008, s. 1035-1045; eadem, Zasady postepowania konserwatorskiego w procesie konserwacii i restauracji zabytkowych wyrobów kaflarskich, [w]: Piece kaflowe w zbiorach muzealnych w Polsce, materialy konferencyjne 5-7 września Frombork 2008, Muг: Mikotaja Kopernika, Frombork 2010, s. 304-312; eadem, Problemy eksposycyjne zab. rzemiosta artystycznego w swietle wymogón konserwatorskich. Materiały V Międzynarodowej Konferencji Konserwatorskiej pt. Problemy muzeów związane z zachowaniem i konserwacją zbiorów. Szreniawa 5-6 październik 2012, Szreniawa 2013, s. 158-173.

4 E. Maryniak-Piaszczyńska, Dok. konserwatorska; dzbanek porcelanowy H. Wolffson 1880-90, wł. prywatna, praca pod kierunkiem mgr Marii Rudy, mps w zbiorach ZKRziDA Toruń 1986; A. Bortkiewicz, Dok. konserwatorska; filiżanka porcelanowa 1897-1907 Selb-Bawaria, wł. prywatna, praca pod kierunkiem mgr Marii Rudy, mps w zbiorach ZKRziDA, Toruń 1987; A. Kozioł, Dok. konserwatorska; japoński wazon porcelanowy z dekoracją typu Imari XIX w.; zbiory MWiM w Olsztynie, praca pod kierunkiem mgr Marii Rudy, mps w zbiorach ZKRziDA, Toruń 1989. Wazon po konserwacji, opisany także w publikacji Grażyny Kobrzenieckiej-Sikorskiej w „Roczniku Olsztyńskim” t. XVIII, 1998; P. Kozub, Dok. konserwatorska; talerz chiński z dynastii Ming; zbiory MN w Gdańsku, praca pod kierunkiem mgr Marii Rudy, mps w zbiorach ZKRziDA Torun 1990/91. B. Nara, Dok. konserwatorska; waza porcelanowa Petersburg 1830-40, zbiory MWiM w Olsztynie; praca pod kierunkiem mgr Marii Rudy, mps w zbiorach ZKRziDA, Toruń 1994; M. Mzyk, Dok. konserwatorska; patera szklana, emaliowana XIX w., wł. prywatna; praca pod kierunkiem mgr Marii Rudy, mps w zbiorach ZKRziDA, Toruń 1995; K. Jurdzińska-Wypych, Dok. konserwatorska; Kalpis, naczynie czerwono-figurowe IV w. p.n.e. Grecja, zbiory Muz. Archeologicznego w Krakowie, praca pod kierunkiem mgr Marii Rudy, mps w zbiorach ZKRziDA, Toruń 1996.

5 H. Granek, Dok. konserwatorska; glazurowany kafel płytowy z przedstawieniem Kuźni Wulkana poł. XVIII w., zbiory MN w Gdańsku, praca dyplomowa pod kierunkiem mgr Marii Rudy, mps w zbiorach ZKRziDA, Toruń 2007; M. Caban, Dok. konserwatorska dwóch obiektów porcelanowych; krater z malowanym przedstawieniem sceny pasterskiej i talerz Rosenthal z angielską sceną myśliwską typu „par force”, wł. prywatna. Prace 
nowatorskiej metody w technologii przygotowania zapraw do uzupełniania ubytków i rekonstrukcji w zabytkowej ceramice, tj. zastosowanie nowego, lekkiego wypełniacza stanowiącego jeden ze składników zapraw - o nazwie Poraver $^{6}$ oraz zaprawy do rekonstrukcji m.in. waz antycznych na bazie gipsów alfa, o podwyższonej wytrzymałości ${ }^{7}$, stosowanych obecnie podczas realizacji prac dyplomowych studentów specjalizacji KRzKiEA, prowadzonych pod kierunkiem autorki, przy zabytkach ceramicznych. Wszystkie zabiegi restauratorskie, obejmujące prace przy uzupełnieniach zarówno czerepów, jak i szkliw w omawianych zabytkach ceramicznych i szklanych (poza nielicznymi wyjątkami), wykonywane są w technologii konserwatorskiej bez wypalania („na zimno”), z zachowaniem odpowiedniego doboru materiałów konserwatorskich - imitacyjnych, zależnego od warunków otoczenia, w jakich eksponowany jest dany zabytek ceramiczny.

\section{Problematyka badawcza i konserwatorska uzupełniania szkliwionych zabytków ceramicznych eksponowanych w warunkach zewnętrznych}

Glazurowane, zabytkowe elementy architektoniczne, pozostające pod wpływem stałego oddziaływania zewnętrznych czynników atmosferycznych, narzucaja konserwatorom, badaczom i technologom ceramiki (współpracującym z konserwatorami) bardziej restrykcyjne wymogi dotyczące trwa-

wraz z częścią eksperymentalną (aneks do ww. dokumentacji), pt. Badania imitacji podłoży porcelanowych oraz opracowań malarskich, wykonanych w technice konserwatorskiej, zastosowanych przy dwóch obiektach porcelanowych: talerza Rosenthal z przedstawieniem angielskiej sceny myśliwskiej typu ,par force” oraz krateru z malowanym przedstawieniem sceny pasterskiej. Prace wykonane pod kierunkiem mgr Marii Rudy, mps trzech dokumentacji w zbiorach ZKRziDA, Toruń 2009.

${ }^{6}$ H. Granek, Dok. konserwatorska...; A. Tomaszewska, Dok. konserwatorska; renesansowy kufel ceramiczny z Brzegu, zbiory archeologiczne Muz. Miejskiego w Brzegu; praca dyplomowa pod kierunkiem mgr Marii Rudy, mps w zbiorach ZKRziDA, Toruń 2008.

M. Buchalik, Dok. konserwatorska; attycka hydria czarno-figurowa VI w. p.n.e., zbiory MN w Poznaniu; praca dyplomowa pod kierunkiem mgr Marii Rudy, mps w zbiorach ZKRziDA, Toruń 2000; D. Dombek, Dok. konserwatorska; lektyt czarno-figurowy $\mathrm{V}$ w. p.n.e., zbiory MN w Poznaniu; praca dyplomowa pod kierunkiem mgr Marii Rudy, mps w zbiorach ZKRziDA, Toruń 2002. 
łości materiałów konserwatorskich na procesy wietrzeniowe zachodzące w środowisku zewnętrznym. Dotyczy to przede wszystkim środków i preparatów iniekcyjnych, stosowanych do wypełniania pęknięć w strukturze ceramiki, składu zapraw imitujących czerepy/podłoża ceramiki porowatej i nieporowatej, warstw angobowych oraz szkliw stanowiących warstwy licowe - dekoracyjne w rzeźbie, a także podkreślające kompozycję i podziały architektoniczne w elewacjach zabytkowych budowli. Odporność warstw szkliwnych oraz trwałość „spojenia” z czerepem zależy m.in. od właściwości podłoży ceramicznych, na których leżą szkliwa, a dokładniej od wzajemnego przenikania się w warstwie przypowierzchniowej, co gwarantuje odpowiednia technologia ceramiczna i szklarska oraz dobór właściwych surowców w procesie przygotowania i wypalania wyrobów.

Podobnie sztuczne glazury stosowane w warunkach zewnętrznych powinny cechować się zdolnością niewielkiego przenikania w zaprawy imitujące podłoża ceramiczne, niezależnie od rodzaju spoiwa tych zapraw (organiczne lub nieorganiczne). Określając zatem wymogi konserwatorskie, jakie powinno spełniać sztuczne szkliwo, nanoszone „na zimno” - bez wypalania, konieczne jest zapewnienie wysokiej adhezji pomiędzy warstwami wierzchnią i spodnia.

Podstawowe cechy, jakie powinny mieć konserwatorskie powłoki imitujące zabytkowa glazurę, sa następujące:

— wysoka odporność na działanie wody

- doskonała przyczepność do podłoża ceramicznego lub/i podłoża imitacyjnego

- trwałość i niezmienność optyczna

— odpowiednia elastyczność

- odporność i trwałość na zmienne warunki temperaturowe

— zbliżona rozszerzalność termiczna do podłoża

- odporność i trwałość na ścieranie.

Spośród wielu materiałów stosowanych w konserwacji i restauracji rzeźby i detali architektonicznych, w tym także w rekonstrukcji i uzupełnianiu szkliw na zabytkach ceramicznych, najwyższą trwałością w warunkach zewnętrznych charakteryzują się tworzywa wielkocząsteczkowe - chemoutwardzalne, takie jak żywice epoksydowe czy poliuretanowe. Sa wśród wielu odmian tych żywic takie, które zostały zbadane jako powłokotwór- 
cze i ochronne warstwy zdobnicze na ceramice, eksponowane w środowisku zewnętrznym ${ }^{8}$. Wśród żywic epoksydowych na uwagę zasługuja żywice alifatyczne, trwałe optycznie oraz te wśród aromatycznych, które mają podwyższoną odporność wietrzeniową i optyczną z racji odpowiednio dobranego utwardzacza lub modyfikacji żywica alifatyczna. Wśród żywic poliuretanowych o cechach powłokotwórczych uwzględnia się odmiany stosowane w przemyśle stoczniowym lub samochodowym, jako lakiery ochronne w agresywnym środowisku wodnym (np. kadłuby okrętów), czy też lakiery ochronne na samochodach, m.in. wyścigowych. Wśród tych ostatnich są także żywice światło trwałe.

Autorka artykułu zetknęła się w latach 90. XX w. z problemem i koniecznością stabilnej ochrony folii złotej, zdobiącej miedziane i brązowe elementy dekoracyjne architektury sakralnej oraz pałacowej. Wraz z prof. dr. hab. Januszem Krauze, specjalistą w zakresie ochrony i konserwacji zabytków metalowych, zastosowaliśmy, po wykonaniu wstępnych badań przez autora pomysłu - J. Krauze, lakier poliuretanowy firmy Du Pont, stosowany jako warstwa ochronna na samochodach wyścigowych. Do dziś trwałość tych powłok na złocie kładzionym ,na mikstion” można obserwować na wieży kościoła św. Floriana na Pradze oraz kościoła Karmelitów w Warszawie, a także na szczycie pałacu w Lubostroniu. Nie najlepiej natomiast zachował się ten lakier ochronny na dziesięciu złoconych (rosyjska folia złota) i malowanych płycinach reliefowych wykonanych z brazu, pochodzących z wystroju Wielkiej Kaskady przed rosyjskim Pałacem Carycy w Peterhofie (Petrodworec) nad Zatoka Fińska, gdzie w 1989 r. pod kierunkiem prof. Janusza Krauze m.in. autorka wykonywała prace w obrębie warstw zdobniczych (malarstwo, złocenia) i powłoki ochronnej. Jak wieść konserwatorska niesie, została ona po pewnym czasie ekspozycji w warunkach

8 K. Fabiańczyk, Badania nad technologia lakierów epoksydonych do uzupetniania i rekonstrukeji sækliw na cegłach; próba ograniczenia wspótczynnika rozszerzalności cieplnej powtok; praca magisterska pod kierunkiem prof. dr. hab. Wiesława Domasłowskiego, w zbiorach ZKRziDA, Toruń 2006; K. Bednarczuk, Metody uzupetniania glazury w ceramicznych detalach architektonicznych, praca magisterska pod kierunkiem prof. dr hab. Jadwigi Łukaszewicz, w zbiorach ZKRziDA, Torun 2006; G. Dorota, Technologia zapraw poliuretanowych do uzupetniania ubytków w kamieniach, praca magisterska pod kierunkiem prof. dr. hab. Wiesława Domasłowskiego, w zbiorach ZKRziDA, Toruń 1996. 
nadmorskich zastapiona inną warstwa zabezpieczającą malowane i złocone lica. Mówiąc o przyczynach niestabilności opisywanej powłoki poliuretanowej, nie można wykluczyć zarówno oddziaływania szkodliwej, agresywnej (chlorkowej) atmosfery nadmorskiej, jak i jej uszkodzeń w trakcie montowania bardzo ciężkich, wielkogabarytowych płycin z brązu, osadzanych w pierwotnej zabudowie Wielkiej Kaskady po ich konserwacji i restauracji wykonanej w Polsce.

Praktyka konserwatorska i restauratorska autorki artykułu w pracach przy rzeźbach zewnętrznych i detalach architektonicznych wykonanych z ceramiki szkliwionej obejmowała zabytki, przy których sprawowała ona konserwatorskie nadzory autorskie, była także koordynatorem badań oraz wykonawca prac przy odtwarzaniu zabytkowej glazury.

W latach 2000-2001 autorka pełniła nadzór konserwatorski przy elewacjach części prezbiterialnej gotyckiego kościoła św. Jakuba w Toruniu, gdzie na wielu oryginalnie szkliwionych kształtkach zdobniczych, zwietrzała i zniszczona glazura została zrekonstruowana lub uzupełniona za pomocą dobranej kolorystycznie warstwy malarskiej w odcieniach jasnej i ciemnej zieleni oraz źółcieni. Jest to farba o cechach hydrofobowych, oparta na spoiwie krzemoorganicznym, zatem nie imituje połysku charakterystycznego dla transparentnych i świetlistych szkliw ołowiowych, wypalonych łącznie z podłożem porowatej ceramiki czerwonej (kształtki i cegły gotyckie). Jej kondycja, poza partią cokołową w przyziemiu murów prezbiterium, jest do dziś zadowalająca, bez widocznych zmian wietrzeniowych, natomiast nie oddaje charakteru lśniących i błyszczących glazur, świadomie kładzionych w elementach zdobniczych wystroju architektonicznego krzyżackich budowli sakralnych, co często podnoszą historycy sztuki w twórczych dyskusjach z konserwatorami.

W latach 2001-2002 autorka tekstu była koordynatorem badań i autorem technologii imitacji glazury dla rzeźby ceramicznej eksponowanej w środowisku zewnętrznym, a także wykonawca prac podczas jej zakładania na zabytkowa ceramikę. Był nim ceramiczny nagrobek Carla Hauptmanna (pocz. XX w.) z Muzeum Karkonoskiego w Szklarskiej Porębie. Pierwotne miejsce jego posadowienia to cmentarz w Szklarskiej Porębie. Autorem prac konserwatorskich i restauratorskich oraz dokumentacji powykonawczej tej wolno stojącej, wieloelementowej ceramicznej rzeźby na- 
grobnej (wys. 2,93m, podstawa: 1,85m x 1,02m) był mgr Tomasz Filar', absolwent specjalności KRzKiDA, którego praca dyplomowa wykonana pod kierunkiem autorki niniejszego tekstu, dotyczyła także dużej, wolno stojącej rzeźby z zabudowy parkowej w Żaganiu. Konsultantem z ramienia Muzeum Okręgowego w Jeleniej Górze był dr Jerzy J. Kunicki-Goldfinger - rzeczoznawca MKiDN ds. konserwacji szkła, ceramiki, emalii i materiałów pokrewnych. Złożona problematyka konserwatorska nagrobka, który w latach 1982-1983 przeszedł w PP PKZ oddział Toruń kompleksową renowację wraz z szeroko zakrojonymi badaniami materiałoznawczymi, dotyczyła również kwestii powtórnej rekonstrukcji wielobarwnych glazur, które we wcześniej użytym materiale nie spełniły wymagań trwałości i stabilności w ekspozycji zewnętrznej. Należy zaznaczyć, że górskie warunki klimatyczne, w jakich posadowiony jest nagrobek, należą do bardziej agresywnych niż te w klimacie nizinnym.

Na podstawie szczegółowej analizy badań technologicznych, petrograficznych oraz instrumentalnych wykonanych podczas poprzedniej konserwacji w latach 80., a także przebiegu prac konserwatorsko-restauratorskich wykonanych przy obiekcie ${ }^{10}$ po jego demontażu z cmentarza w Szklarskiej Porębie (zabytek częściowo rozbity) i przewiezieniu do pracowni PKZ w Toruniu - określono wymogi konserwatorskie związane z doborem materiałów do ponownej imitacji szkliw kładzionych bez wypalania - „na zimno". Miały być kładzione na istniejących podłożach zarówno oryginalnych (ceramika czerwona o niskiej porowatości), jak i na zaprawach konserwatorskich w większości pozostawionych z poprzedniej konserwacji. Zatem sztuczna glazurę nakładano na hydrofobowe powierzchnie czerepu (po jego wcześniejszej hydrofobizacji) oraz hydrofobowe zaprawy epoksydowe z dodatkiem odpowiednio dobranych kruszyw i wypełniaczy.

9 T. Filar, Dokumentacja konserwatorsko-restauratorska; ceramiczny nagrobek Carla Hauptmanna autorstwa Hansa i Marlene Poelzingón z. Muzeum Karkonowskiego w Szklarskiej Porębie, Olsztyn 2002.

10 Dokładny opis zastosowanych materiałów i metod zamieszczono w „Dokumentacji konserwatorskiej nagrobka Carla Hauptmanna ze Szklarskiej Poręby”, opracowanej w 1982-1983 r. przez PKZ Oddz. Toruń - Pracownia Konserwacji Kamienia. 


\section{Szkliwiony, ceramiczny pomnik nagrobny Carla Hauptmanna w pierwotnym miejscu posadowienia - na cmentarzu w Szklarskiej Porębie}

Przed przystapieniem do wyboru nowej technologii w procesie nanoszenia imitacji glazury autorka przygotowała próbki z różnymi wariantami sztucznych szkliw, które poddane zostały w 2001 r. badaniom starzeniowym w Laboratorium Naukowo-Badawczym PKZ w Toruniu (wyniki badań przedstawiono w Załaczniku 1). Sztuczne szkliwa nałożono na identyczne podłoża - zaprawy epoksydowe użyte podczas wcześniejszej konserwacji z lat 80 . We wszystkich próbkach uwzględniono warstwowe nakładanie sztucznych glazur, przyjmując (podobnie jak w ceramice angobowanej, a następnie szkliwionej) istnienie znacznych różnic we współczynniku rozszerzalności termicznej między porowatym podłożem a szczelną - nieporowata, wierzchnią warstwą lakieru imitacyjnego epoksydowego lub poliuretanowego. W przypadku sztucznej glazury funkcje niwelowania naprężeń między podłożem a powłoką lakierową pełnić miały warstwy gruntu podkładowego (rodzaj angoby) wraz z matową warstwą malarską o dużej trwałości optycznej i na wietrzenie, która odtwarzała wielobarwną kolorystykę szkliw oryginalnych. Dopiero na niej nakładana była cienka warstwa lakieru z nieżółknącej żywicy epoksydowej, spełniającej wyżej przedstawione wymagania konserwatorskie. W tym wariancie ze szklista, błyszcząca powłoka końcowa (Gloss) autorka wybrała zarówno różne materiałowo i odpornościowo podłoża, jak i matowe lub satynowe warstwy malarskie. Drugi wariant (Matt) dotyczył próbek z malatura matowa, bez imitacji glazury, która miała naśladować oryginalne zdobienia matowe (nieszkliwione na nagrobku).

Zestawienie wszystkich badanych, opisanych wyżej i w Załaczniku 1, a także fotografowanych próbek w formie bardziej szczegółowych ujęć, wykonanych obecnie przez autorkę dla potrzeb artykułu, przedstawiono poniżej. 
Wyniki wykonanych badań starzeniowych (testy mrozoodporności i długotrwałe działanie wody na warstwy imitacyjne, zróżnicowane składem), przeprowadzonych w warunkach laboratoryjnych, wykazały zasadność zastosowania technologii malarskiej z użyciem odpornego na wietrzenie gruntu/podkładu malarskiego, następnie matowej warstwy opracowania barwnego (obie warstwy porowate i hydrofobowe), a na końcu - powłoki żywicy chemoutwardzalnej o wysokim połysku i świetlistej głębi, kładzionej w jak najcieńszej warstwie.

W przypadku nagrobka Carla Hauptmanna zastosowaną warstwa podkładową w obu wariantach (Gloss i Matt) była ,gruntówka” firmy Tikkurila Presto LV - do użytku w warunkach zewnętrznych. Opracowania barwne oparte na bazie związków krzemoorganicznych z wybranymi pigmentami konserwatorskimi różniły się w obu wariantach postacią żywicy. Do wersji Gloss użyto odpowiednio barwionego w masie roztworu żywicy krzemoorganicznej Ahydrosil-Z (obecnie Konsil-Z), który gwarantował częściowe wnikanie w podłoże (lepsze „kotwiczenie”), natomiast do wersji Matt - emulsję silikonową Funcosil WS ${ }^{\circledR}$ odpowiednio barwioną w masie. Cienko kładziona, transparentną powłokę lakierową imitującą szklisty połysk glazury uzyskano z alifatycznej żywicy epoksydowej Hxtal NYL-1 (USA), o wyjściowej niskiej lepkości, której trwałość optyczna i starzeniowa opisana jest w literaturze konserwatorskiej na świecie i w Polsce.

Idea stosowania podkładu gruntowego pod błyszczacca, żywiczną warstwę imitacyjna została także potwierdzona badaniami opisanymi w pracy magisterskiej studentki specjalności KRzKiDA, wykonanymi pod kierunkiem prof. Wiesława Domasłowskiego w 2006 roku ${ }^{11}$.

Po sześciu latach od zakończenia ponownej konserwacji i restauracji nagrobka Carla Hauptmanna, tj. w 2008 roku, dokonano szczegółowego przeglądu zabytku, osadzonego na niskim cokole przed budynkiem $\mathrm{Mu}$ zeum K. w Szklarskiej Porębie i chronionego przed wodą opadową dekoracyjnym zadaszeniem. Dokonano wówczas korekt konserwatorskich w obrębie spękanych zapraw spoinowych wprowadzonych pomiędzy blokami ceramicznych elementów, zestawionych z sobą i tworzących potężną

11 K. Fabiańczyk, Badania nad technologia lakierów epoksydonyych..., s. 54-56 i 106-108. 
bryłę rzeźby, a także w obrębie nielicznych spękań w masie brył ceramicznych, na granicy czerpu i zapraw epoksydowych, imitujących oryginalne podłoże. Innym, ważnym spostrzeżeniem było delikatne złuszczanie się cienkiej powłoki żywicznej na licu detali zdobniczych, od strony południowo-zachodniej nagrobka, tj. od strony pobliskich gór, skąd wieją najsilniejsze wiatry. Natomiast warstwy wszystkich matowych polichromii nie uległy żadnym zmianom. W wyniku przeprowadzonego przeglądu konserwatorskiego i wykonania prac korekcyjnych zdecydowano o lokalnym usunięciu mechanicznym łusek powłoki epoksydowej, a w jej miejsce naniesiono opisany wyżej lakier poliuretanowy firmy Du Pont, stosowany jako powłoki ochronne na karoseriach samochodów wyścigowych.

Po kolejnych sześciu latach od czasu wykonania kosmetycznych prac konserwatorskich w 2008 r. stan zachowania nagrobka jest w większości zadowalający w obszarach uzupełnień i rekonstrukcji warstw imitujących glazurę, poza niektórymi partiami od strony południowo-zachodniej, gdzie oddziałuja największe szoki temperaturowe i wiatry, powodując lokalne złuszczenia powłoki wierzchniej. Nadal pojawiają się miejscowe mikropęknięcia i spękania na granicy materiału ceramicznego i zapraw spoinowych czy rekonstrukcyjnych. Zakres ich występowania jest niewielki, jednakże cykliczna korekta konserwatorska, jak wykazują dotychczasowe przeglądy, finansowane niewielkimi środkami przez Muzeum K. w Szklarskiej Porębie, jest niezbędnym warunkiem utrzymania zabytku w dobrej kondycji.

Zdjęcia nagrobka (fot. 1-8) z marca br. ukazuja jego stan obecny.

W ciagu ostatnich kilku lat w ramach prac dyplomowych ${ }^{12}$ lub nadzoru konserwatorskiego autorka niniejszego tekstu prowadziła prace przy zabytkowych zewnętrznych rzeźbach i detalach architektonicznych zdobionych

12 K. Czyż, Dok. konserwatorska; ceramiczna głowa kobiety „Gejszy” z lat 30. XX w. z domu Handlowego „RENOMA” we Wrocławiu; praca dyplomowa pod kierunkiem mgr Marii Rudy i mgr Katarzyny Polak, mps w zbiorach ZKRziDA, Toruń 2009; A. Górniak, Dok. konserwatorska; szkliwione ceramiczne figurki czterech świętych z kościoła pw. św. Katarzyny Aleksandryjskiej w Grzywnie; praca dyplomowa pod kierunkiem mgr Marii Rudy, mps w zbiorach ZKRziDA, Toruń 2012; A. Lora, Dok. konserwatorska; XIX-wieczna, szkliwiona terakotowa rzeźba Madonny z Dzieciątkiem z kościoła pw. Św. Katarzyny Aleksandryjskiej w Grzywnie; praca dyplomowa pod kierunkiem mgr Marii Rudy i mgr Aleksandry Gralińskiej-Grubeckiej, mps w zbiorach ZKRziDA, Toruń 2011-2013. 
szkliwami, przy których ubytki glazur uzupełniane były warstwami imitacyjnymi „na zimno”, zgodnie z opisaną wyżej technologia konserwatorska, z zastosowaniem alifatycznych żywic epoksydowych w postaci lakierów powłokotwórczych, stosowanych m.in. w pracach konserwatorskich lub lakierów poliuretanowych samochodowych, a także używanych w pracowniach rzeźbiarskich przy tworzeniu przejrzystych modeli, budowy prototypów, produkcji soczewek oraz stosowanych jako zewnętrzne warstwy ochronne.

Ważnym ulepszeniem technologicznym, gwarantującym większą trwałość powłok w środowisku zewnętrznym, w przypadku gdy uzupełnienia i rekonstrukcje szkliw leżą na podłożach mineralnych, jest obniżenie współczynnika rozszerzalności termicznej utwardzonego lakieru żywicznego imitującego szkliwa poprzez dodatek do żywicy niewielkiej ilości kruszywa mineralnego w formie mączki kamiennej, co gwarantuje zbliżenie rozszerzalności cieplnej powłoki organicznej-żywicznej do wielkości charakterystycznej dla podłoży mineralnych (ceramika, kwarc, szkliwo). Przy sztucznych glazurach gotyckich dodatek różnej wielkości ziaren kwarcu nadaje powłoce zbliżony walor nierównej i ręcznie wykonywanej pracy ceramika. Jedna z ostatnich większych realizacji konserwatorskich przy gotyckich detalach ceramicznych były wielobarwne płytki/kafle fryzowe i parapetowe na wieży kościoła pw. Św. Jana w Gdańsku, gdzie w 2012 r. autorka pełniłam nadzór konserwatorski, uczestnicząc w opracowaniu programu prac i technologii wykonawstwa konserwatorskiego przy tych cennych, szkliwionych elementach architektonicznych. Agresywne, „chlorkowe” środowisko nadmorskie będzie sprawdzianem dla trwałości lakierów poliuretanowych Du Pont’a, nałożonych na uzupełnienia z wcześniejszym podmalowaniem i podłożem gruntowym, z zastosowaniem technologii konserwatorskiej.

\section{Summary}

\section{The Study and Conservation of Antique Glazed Ceramics in Sculpture and Architectural Detail}

The paper discusses a problem of conservation-related nature that concerns the gradual identification of issues pertaining to the conservation and restoration of antique ceramics based on personal research as well as the practical experience acquired and developed throughout the years as an academic tutor and as a su- 
pervisor of master's dissertations, since the establishment of the Studio of Architectonic Elements and Details Conservation.

Since the 1970s, the author has been conducting conservation practice in the field of artistic and utilitarian ceramics, among others, as well as carrying out technological and materials science research on antique porous and non-porous materials, such as ceramics support or layers of glazed decoration.

All restorative procedures encompassing work over fillings in both bodies as well as types of glaze in ceramic and glass objects (with the exclusion of a few exceptions) were conducted with the use of ("cold") conservation technology without firing, yet with maintaining appropriate conservation - imitative materials which depend on the exhibiting conditions of a given ceramic piece.

The research problem discussed focuses on issues relating to the weathering resistance of cold glazed conservation fillings in antique ceramics located in outdoor contexts. The results of the research-verified variant materials technology as well as the technique of glazed conservation fillings preparation were tested in an antique ceramic object exhibited in outdoor context for many years; the discussion is supplemented with an evaluation of the elements' weathering resistance.

$$
* * *
$$

\title{
ZAŁACZNIK 1
}

PP Pracownie Konserwacji Zabytków Laboratorium Naukowo-Badawcze w Toruniu

\author{
Badania trwałości \\ powłok malarskich imitujących szkliwo \\ Wykonawcy: \\ mgr Dorota Sobkowiak \\ techn. Grzegorz Zapałowski
}

Toruń 2001

W Laboratorium PP PKZ-Toruń wykonano badania przyspieszonego starzenia próbek zapraw, na których położono podkład malarski, wymalowanie i powłoki imitujące szkliwo. 


\section{Skład warstw podkładowych i malarskich}

Próby przygotowano na zaprawie epoksydowej o następującym składzie: żywica epoksydowa (z utwardzaczem) i piasek w proporcji 1: 10. $\mathrm{Na}$ część podłoży nałożono warstwę podkładową z zastosowaniem modyfikowanego gipsu o podwyższonej trwałości, na drugą zaś część mineralną szpachlówkę Presto LV firmy Tikkurilla.

$\mathrm{Na}$ przygotowane $\mathrm{w}$ ten sposób próby nałożono wymalowanie w kilku technikach.

Część prób wykończono lakierem HXTAL NYL-1 imitującym szkliwo, drugą część pozostawiono bez powłoki lakierowej.

Skład powłok malarskich podano w tabeli 1 i 2.

Tabela 1. Skład powłok malarskich (Gloss)

\begin{tabular}{|c|l|l|}
\hline Nr pr. & \multicolumn{1}{|c|}{ Podkład } & \multicolumn{1}{c|}{ Powłoki malarskie } \\
\hline 1 & gips & Ahydrosil Z + pigmenty \\
\hline 2 & gips & Paraloid B-72 $(7,5 \%)+$ pigmenty \\
\hline 3 & gips & Farby akrylowe Tallens'a \\
\hline 4 & gips & Spoiwo silikonowe Remmers'a WS; emulsja silikonowa + pigmenty \\
\hline 5 & gips & Farby żywiczne Maimeri \\
\hline 6 & Presto LV & Emulsja silikonowa WS Remmers'a + pigmenty \\
\hline 7 & Presto LV & Grunt silikonowy Renova Tikkurilla + pigmenty \\
\hline 8 & Presto LV & Restauro Lasur Keim'a \\
\hline & D Lakier imitujący szkliwo Hxtal NYL-1 \\
\hline
\end{tabular}

Tabela 2. Skład powłok malarskich (Matt)

\begin{tabular}{|c|c|l|}
\hline Nr pr. & Podkład & \multicolumn{1}{c|}{ Powłoki malarskie } \\
\hline 1 & - & Ahydrosil Z + pigmenty \\
\hline 2 & - & Paraloid B-72 $(7,5 \%)+$ pigmenty \\
\hline 3 & - & Farby akrylowe Tallens'a \\
\hline 4 & - & Spoiwo silikonowe Remmers'a WS; emulsja silikonowa + pigmenty \\
\hline 7 & Presto LV & Grunt silikonowy Renova Tikkurilla + pigmenty \\
\hline
\end{tabular}




\section{Warunki doświadczenia}

$\mathrm{Na}$ przygotowanych próbkach wykonano testy trwałości powłok w następujących warunkach:

mrozoodporność

nasycanie woda 6 godz. $+20^{\circ} \mathrm{C}$

zamrażanie 18 godz. $-20^{\circ} \mathrm{C}$

komora deszczowa

zraszanie woda $+20^{\circ} \mathrm{C}-500 \mathrm{~h}$

Część prób pozostawiono w normalnych warunkach laboratoryjnych, tj. $+20^{\circ} \mathrm{C}$ i wilgotności wzgl. $50-55 \%$ (próby kontrolne)

Po zakończeniu każdego cyklu mrozoodporności obserwowano stan warstw malarskich, doświadczenie zakończono po 20 cyklach, dokumentując fotograficznie stan powierzchni prób.

Po upływie 500h poddania prób natryskowi wodą wyjęto je, wysuszono i zadokumentowano na fotografiach, porównując stan powierzchni starzonych prób z próbkami kontrolnymi (fot. 1-3).

\section{Wyniki doświadczenia}

Porównując stan zachowania powłok po wykonaniu badan starzeniowych, można stwierdzić, że najsłabiej zachowana jest próba nr 4, a następnie nr 2 w wersji Gloss (warstwy podkładowe z modyfikowanego gipsu, emulsja silikonowa WS ${ }^{\circledR}+$ pigmenty [pr. 4] oraz Paraloid B-72 + pigmenty [pr. 2]; lakier imitujący szkliwo) poddane testowi mrozoodporności. Na powierzchni obu prób widoczny jest pęcherz; większy w próbie nr 4. Pozostałe próby z obu testów charakteryzuja się dobrym stanem zachowania, nie stwierdzono uszkodzeń powłok malarskich czy też wyraźnej utraty połysku.

Obserwacje wymalowań w porównaniu z próbami kontrolnymi prowadzą do wniosku, że powłoki malarskie sa nieco lepiej zachowane, gdy założono je na grunt Presto LV, natomiast gdy zastosowano jako warstwę podkładową modyfikowany gips, powłoki malarskie w niewielkim stopniu traca połysk, co można zauważyć w przypadku prób: 1, 2, 3 i 5 w wersji z cieniej zakładaną malaturą.

Matowe powłoki malarskie są na ogół dobrze zachowane po zakończeniu testów starzeniowych, w tym wypadku nie stosowano gipsu jako warstwy podkładowej. 


\section{Wnioski}

Oceniając poszczególne kompozycje wymalowań, a zwłaszcza ich stan zachowania po przeprowadzeniu testów przyspieszonego starzenia w warunkach imitujących zewnętrzne czynniki atmosferyczne, należałoby wyżej ocenić zastosowanie szpachli Presto LV jako warstwy podkładowej. Spośród zaproponowanych technik wymalowań najlepszy efekt uzyskano dla próbki nr 7, w której na warstwie Presto LV nałożono grunt silikonowy Renova Tikkurilla z pigmentami. Próbka ta z naniesionym lakierem imitującym szkliwo, jak też bez tego lakieru (fot. 3), wykazuje dużą odporność na zewnętrzne warunki atmosferyczne. 


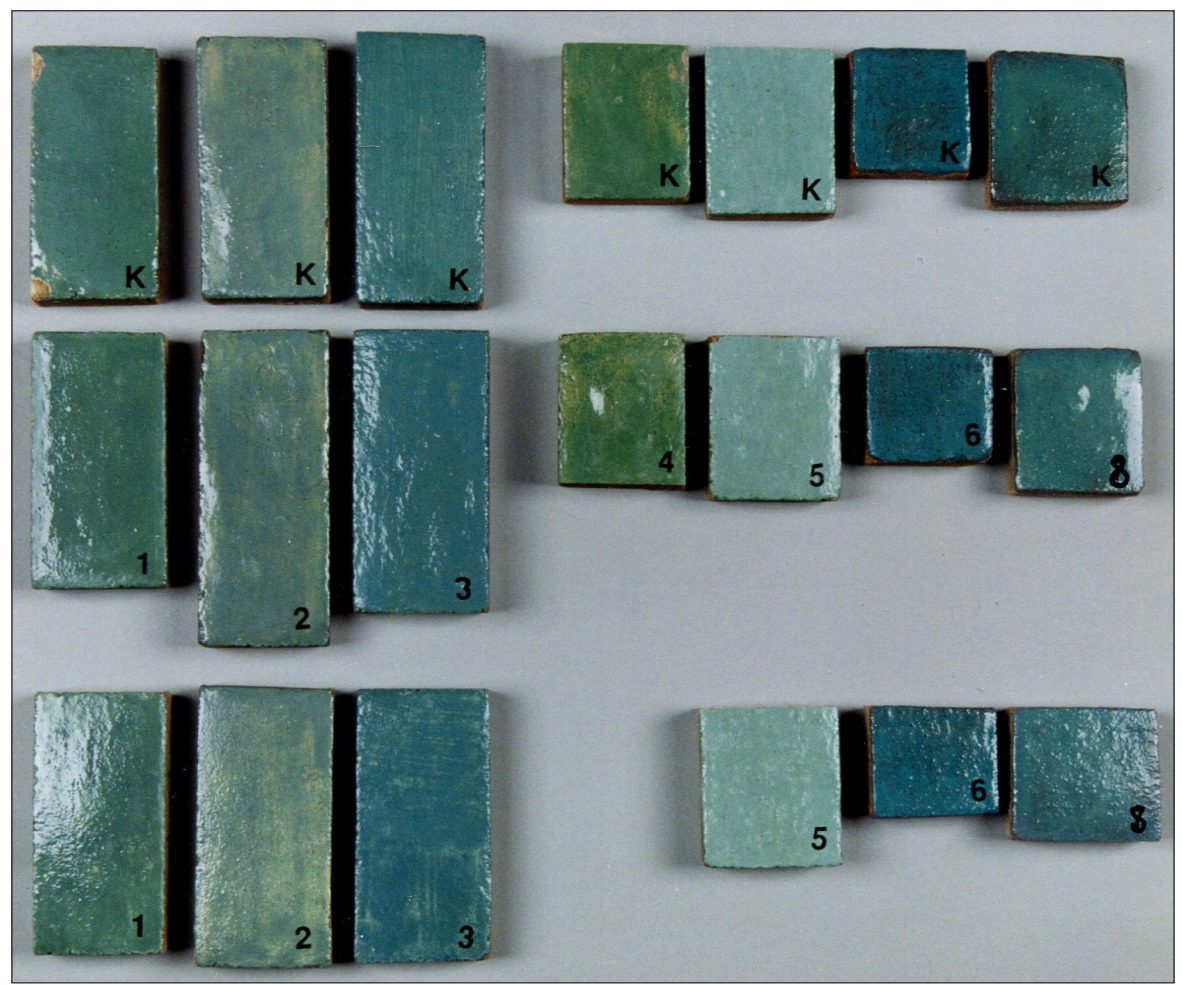

Zał. fot. 1. Stan prób po testach starzeniowych (gloss)

Rząd górny - próby kontrolne

Rząd środkowy - próby po 20 cyklach mrozoodporności

Rząd dolny - próby po 500 h zraszania

Na powierzchni próby 4 i 2 występuje spęcherzenie warstw wierzchnich 


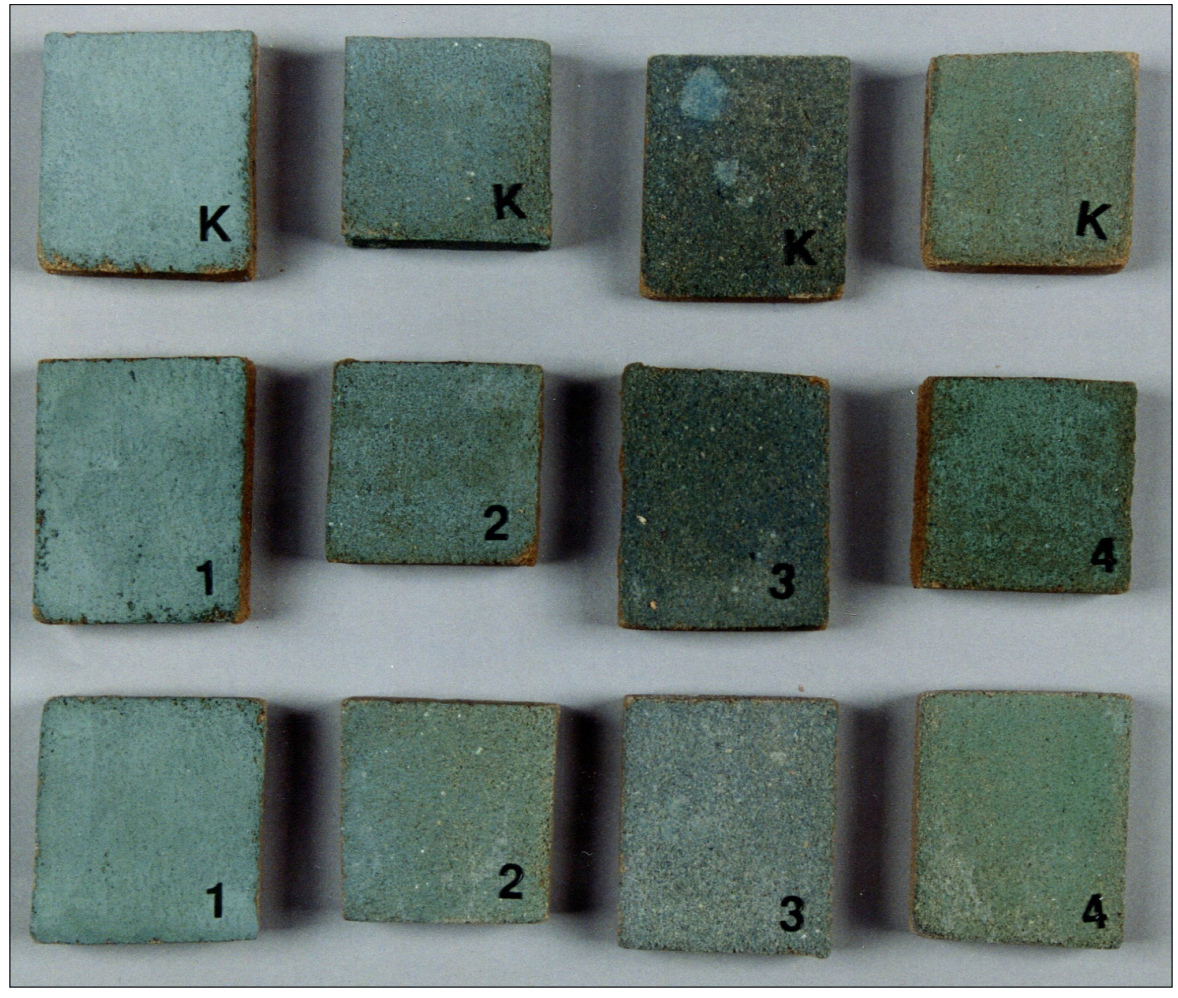

Zał. fot. 2. Stan prób po testach starzeniowych (matt)

Rząd górny - próby kontrolne

Rząd środkowy - próby po 20 cyklach mrozoodporności

Rząd dolny - próby po 500 h zraszania 


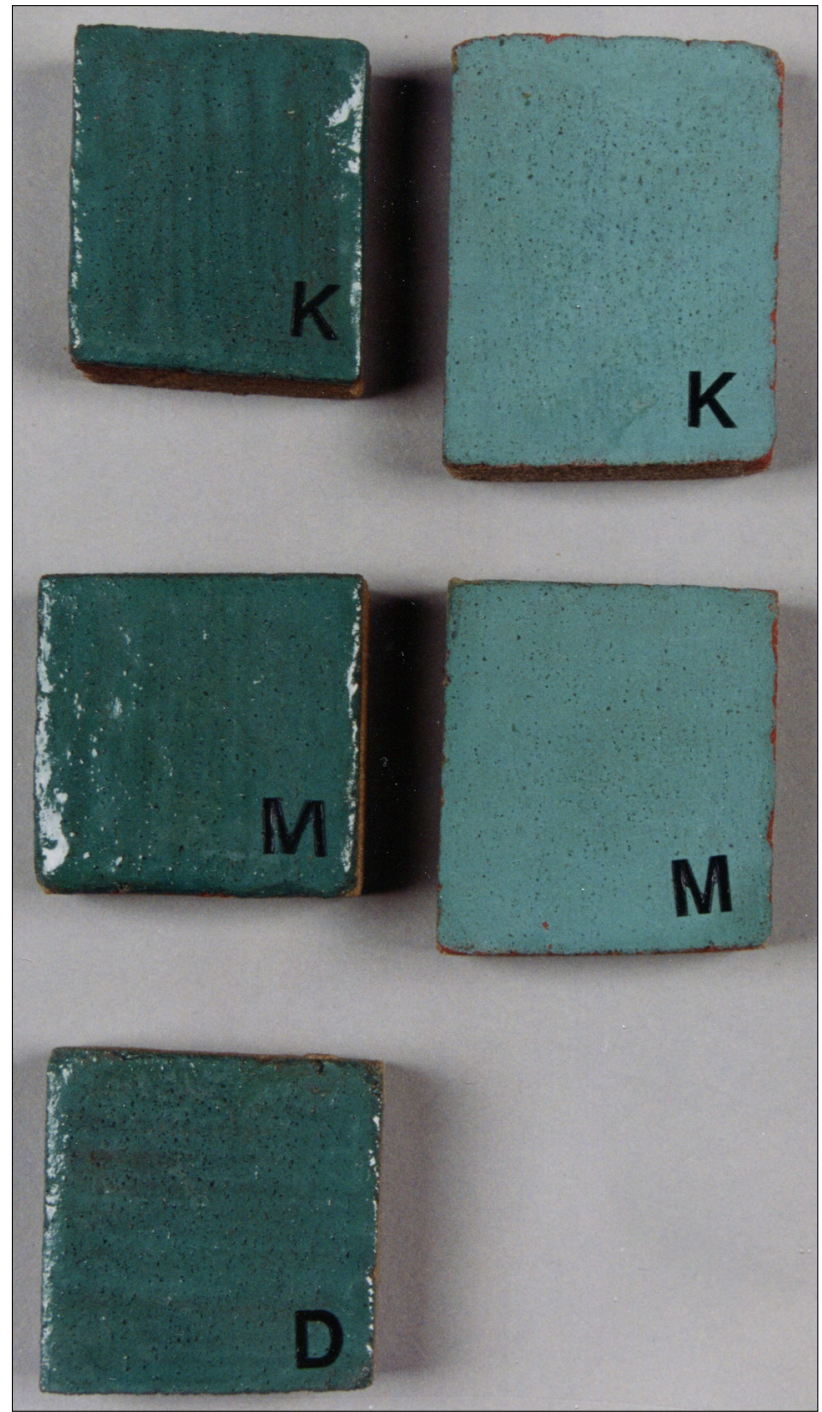

Zał. fot. 3. Próba nr 7 po testach starzeniowych (gloss i matt)

Rząd górny - próby kontrolne

Rząd środkowy - próby po 20 cyklach mrozoodporności Rząd dolny - próby po 500 h zraszania 


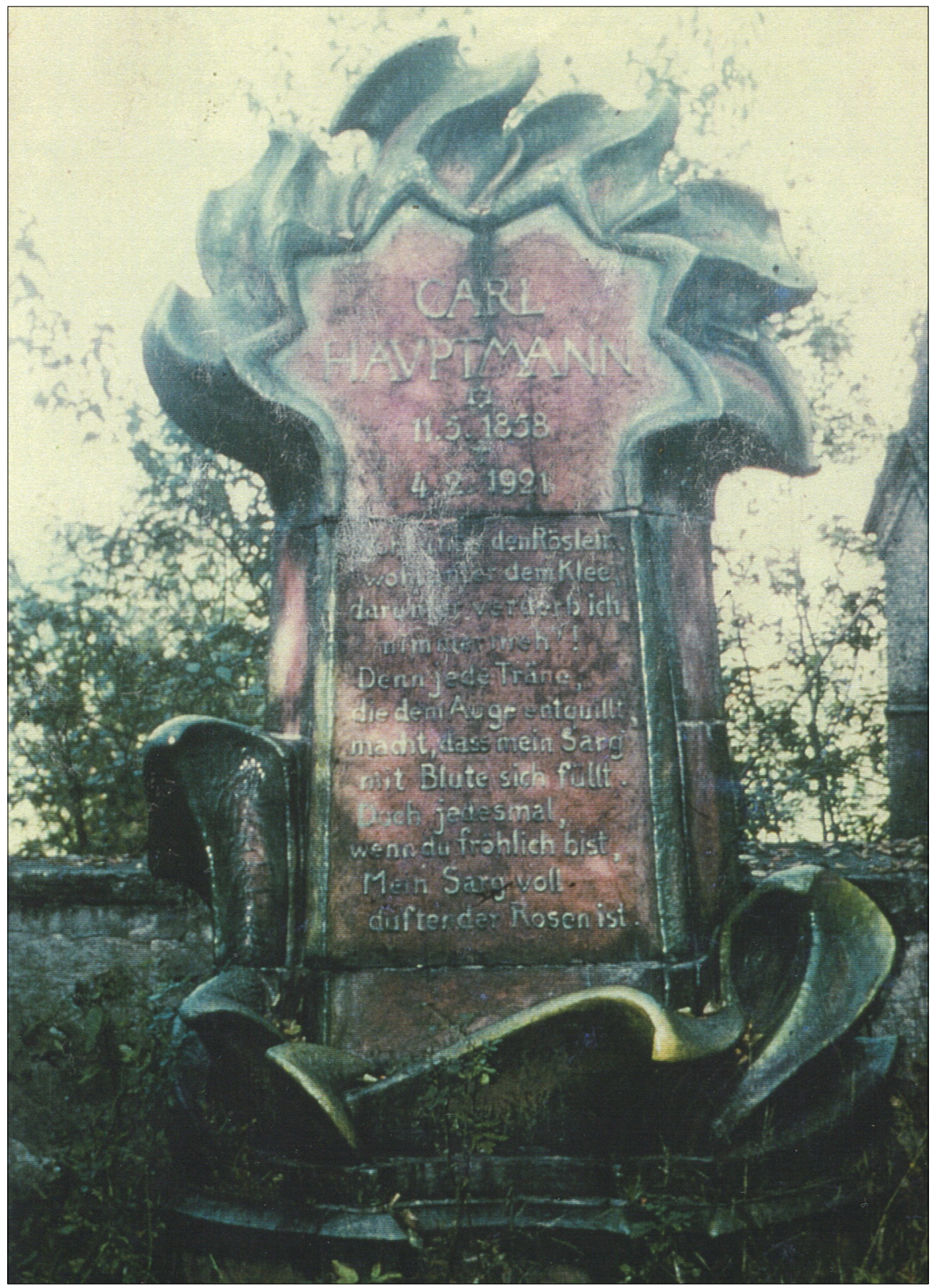

Fot. 1. Szkliwiony, ceramiczny pomnik nagrobny Carla Hauptmanna w pierwotnym miejscu posadowienia, na cmentarzu w Szklarskiej Porębie; stan przed uszkodzeniem. Fot. zbiory PP PKZ - pracownia konserwacji kamienia 


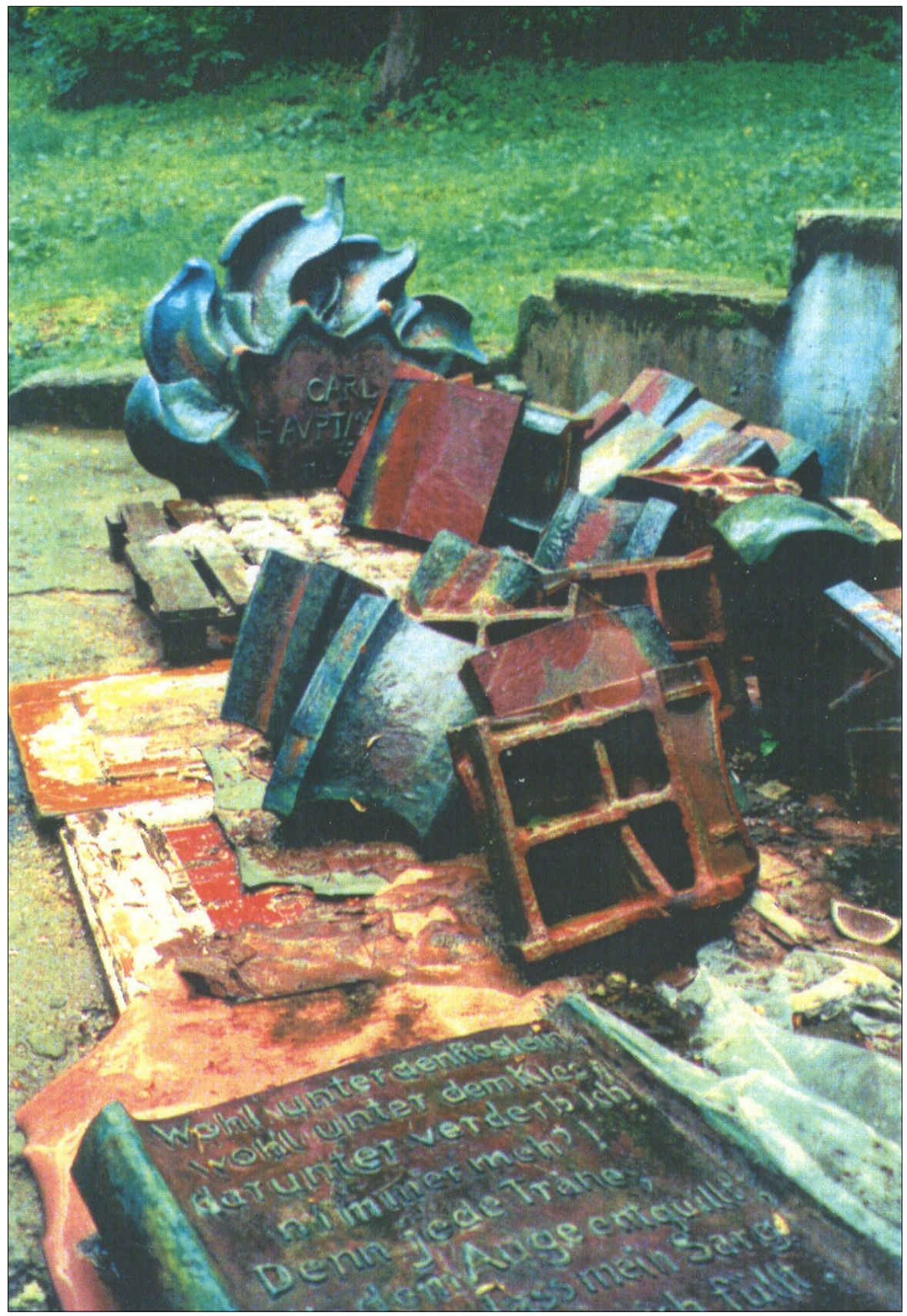

Fot. 2. Jak wyżej stan po dewastacji. Fot. zbiory PP PKZ - pracownia konserwacji kamienia 


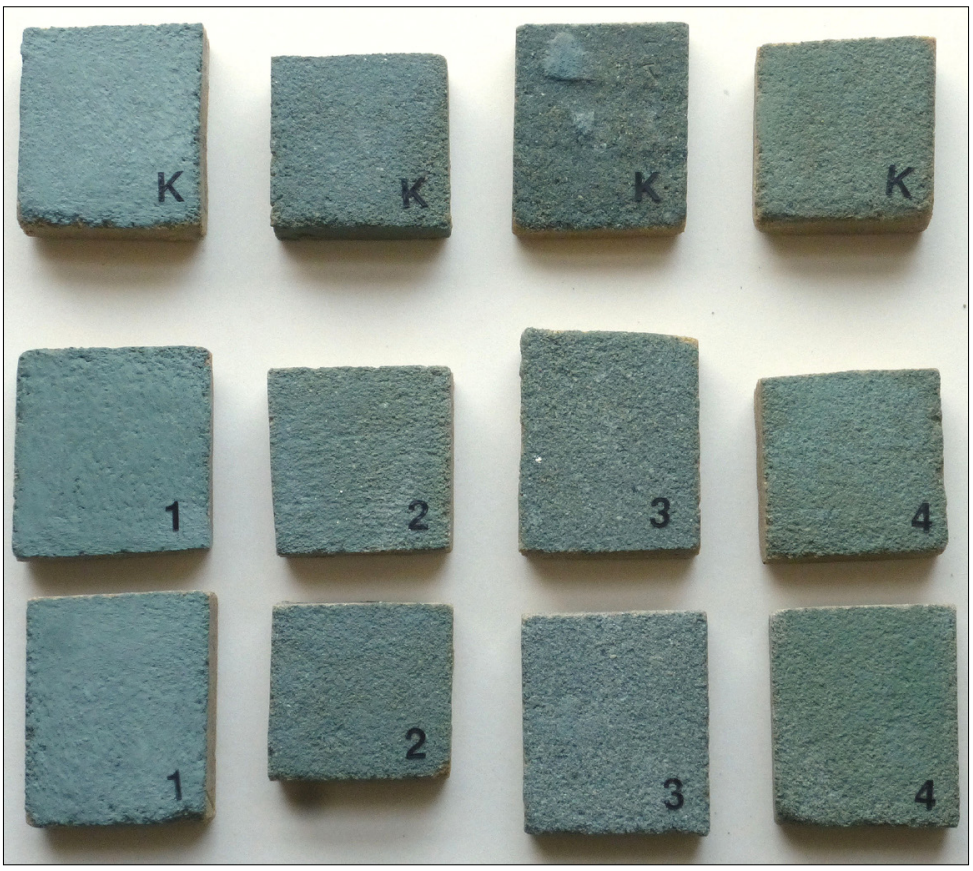

Fot. 3. Wariant MATT (próbki 1-4). Fot. Maria Rudy

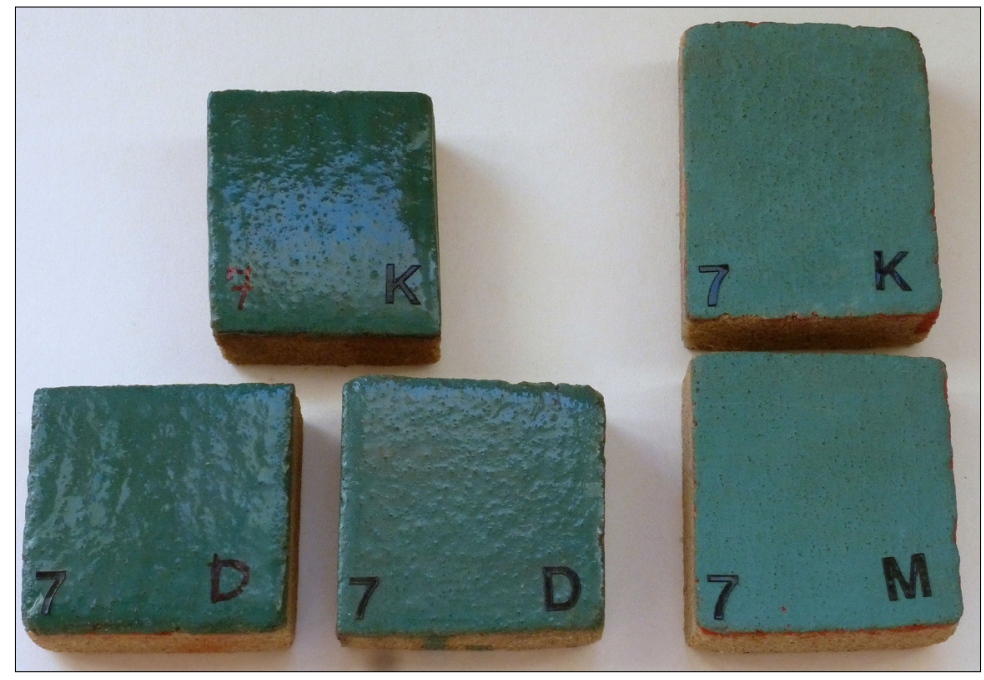

Fot. 4. Wariant GLOSS i MATT (pr. 7). Fot. M. Rudy 


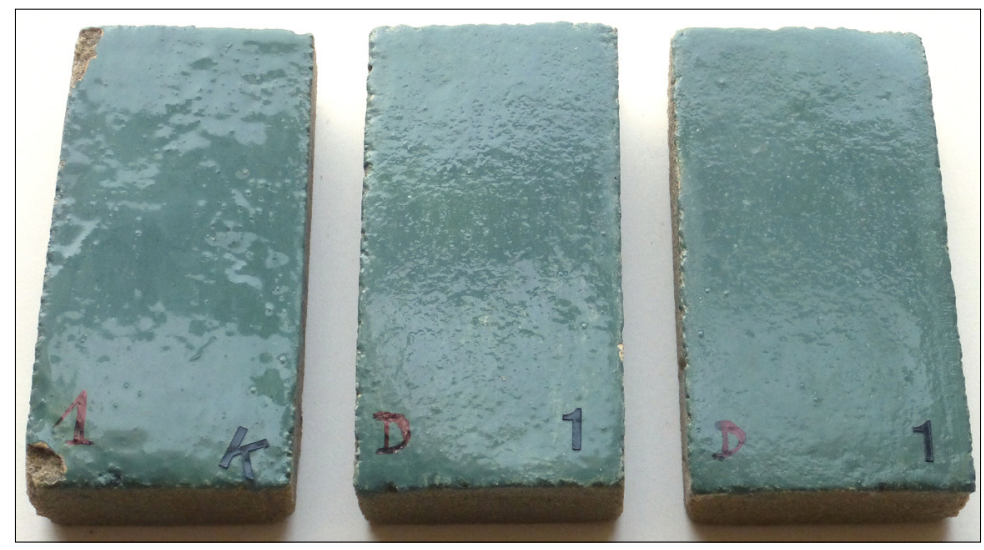

Fot. 5. Wariant GLOSS (pr. 1). Fot. M. Rudy

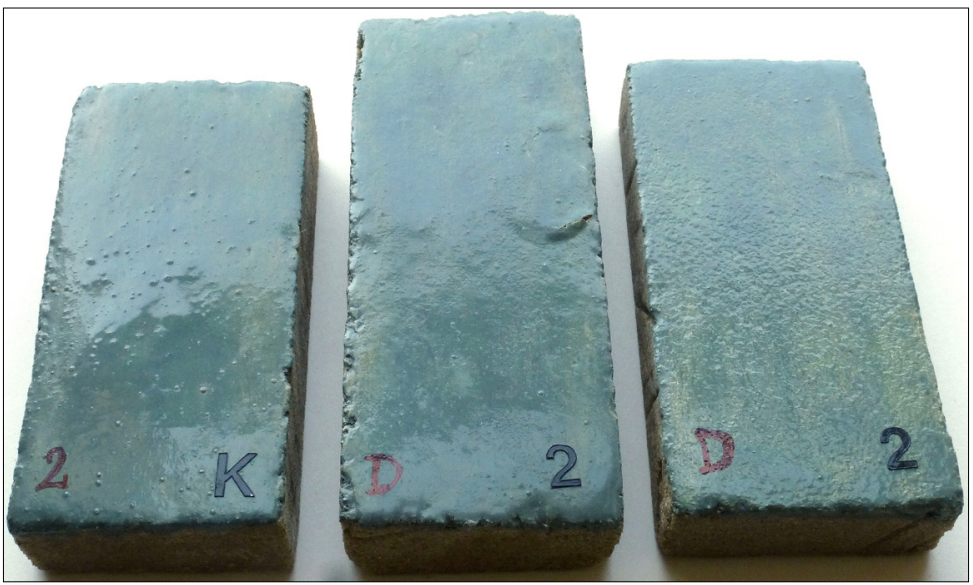

Fot. 6. Wariant GLOSS (pr. 2). Fot. M. Rudy 
[358]

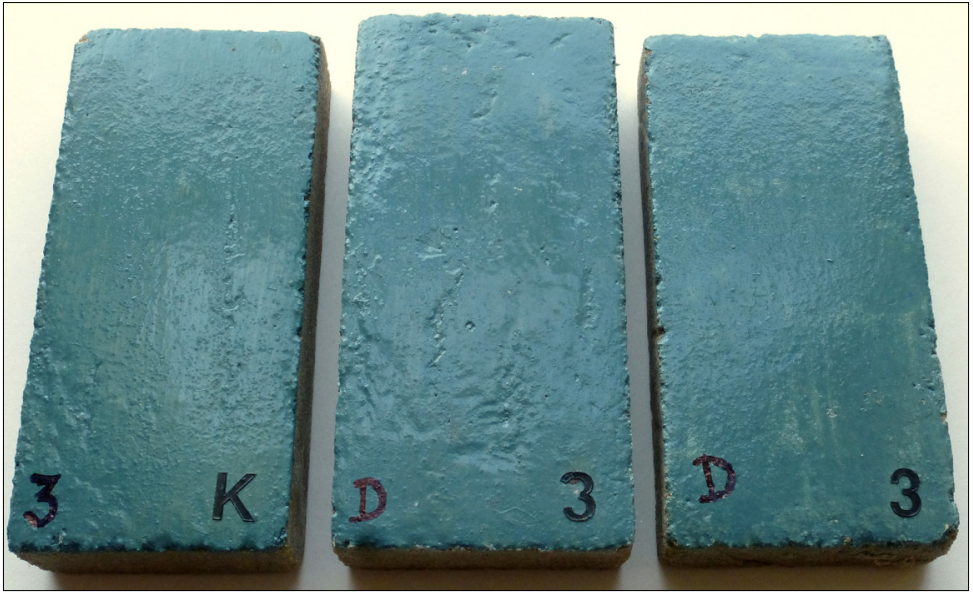

Fot. 7. Wariant GLOSS (pr. 3). Fot. M. Rudy

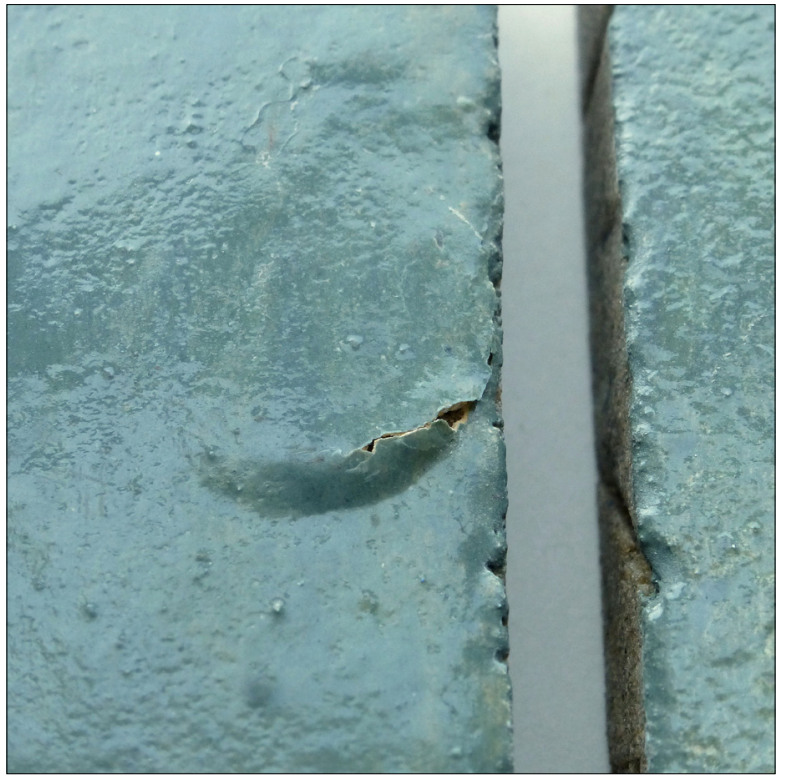

Fot. 8. Spęcherzenie warstwy malarskiej z gruntem (pr. 2). Fot. M. Rudy 


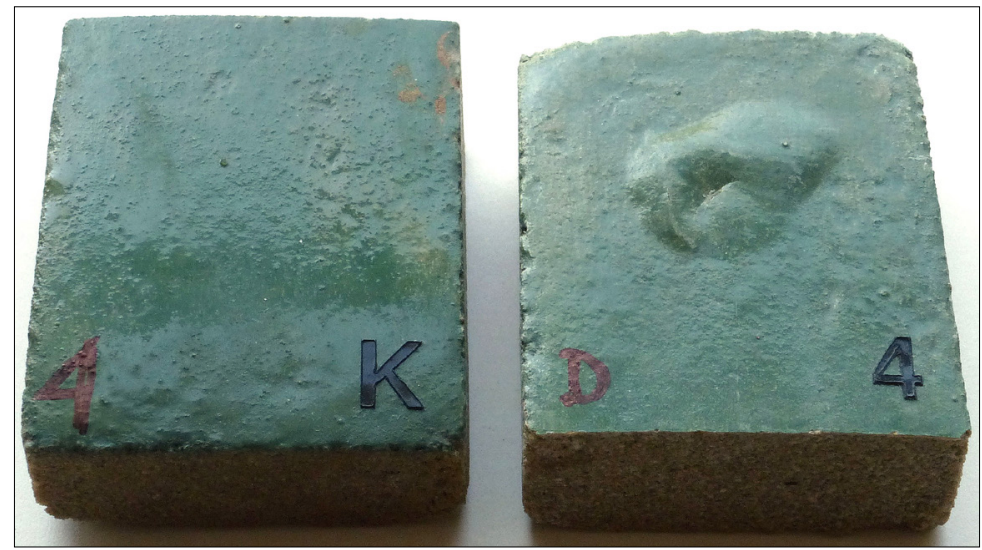

Fot. 9. Wariant GLOSS (pr. 4 z pęcherzem). Fot. M. Rudy

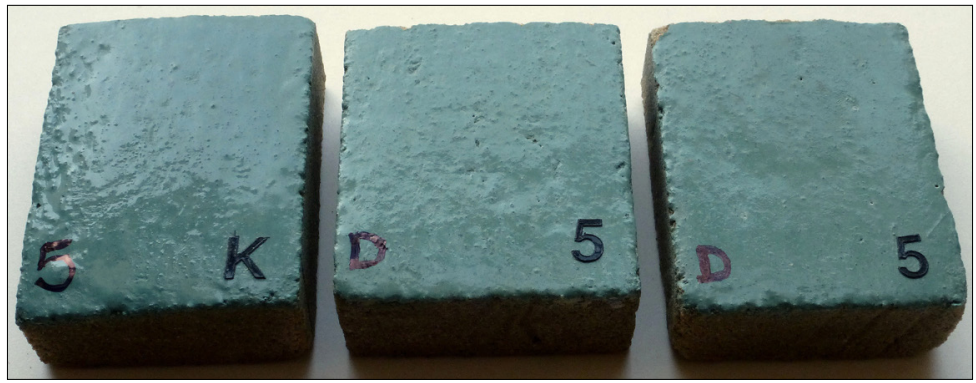

Fot. 10. Wariant GLOSS (pr. 5). Fot. M. Rudy

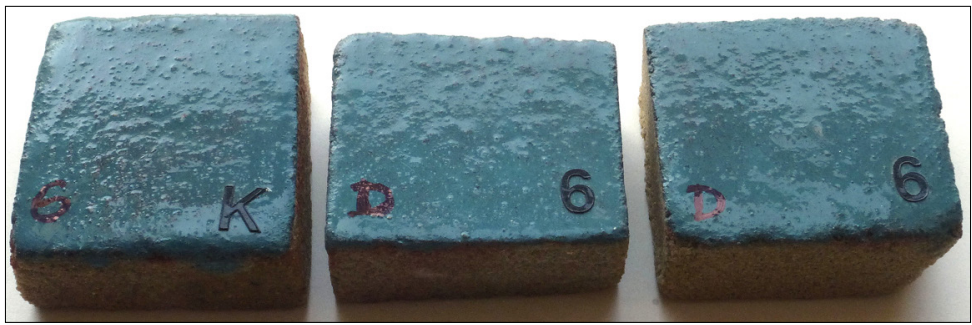

Fot. 11. Wariant GLOSS (pr. 6). Fot. M. Rudy 


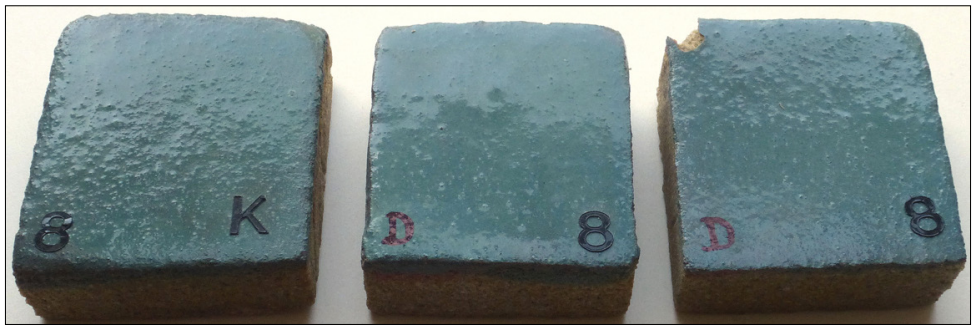

Fot. 12. Wariant GLOSS (pr. 8). Fot. M. Rudy

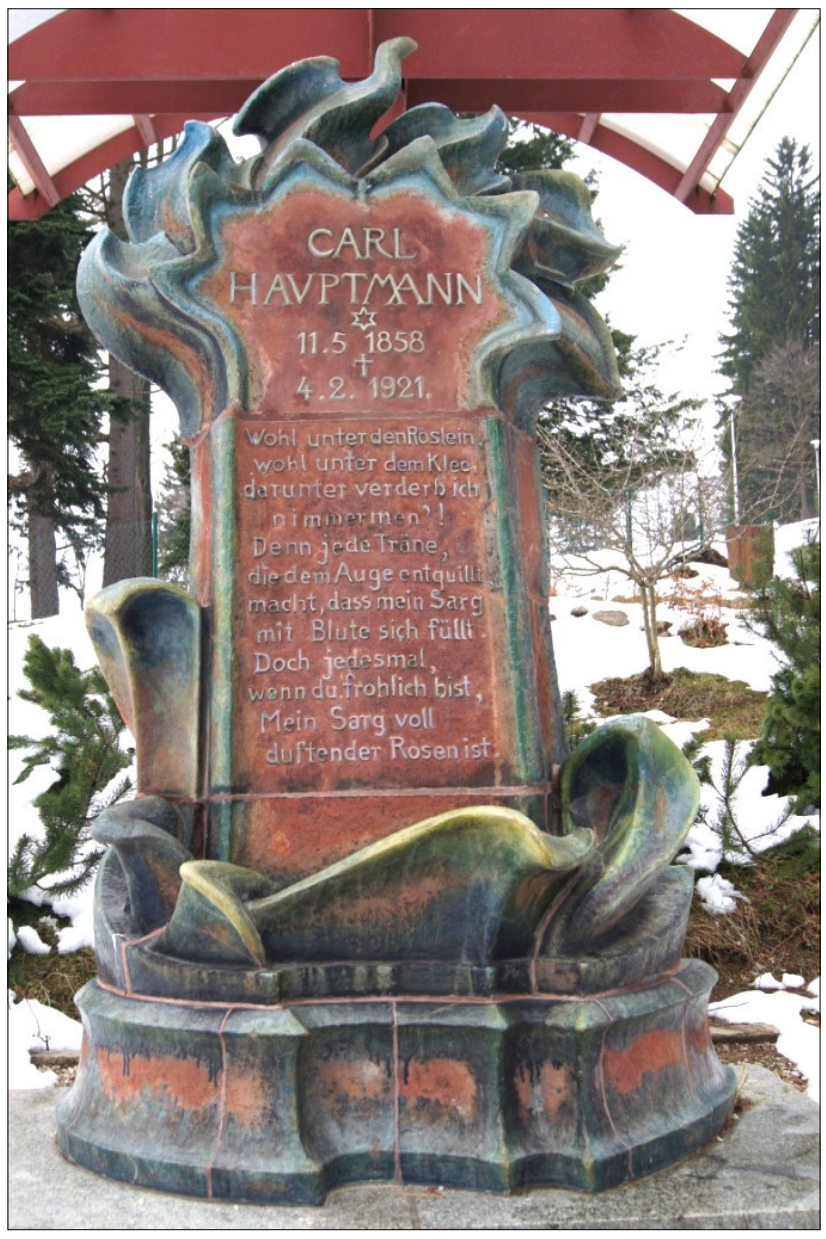

Fot. 13. Nagrobek Carla Hauptmanna; stan obecny. Fot. A. Gul 


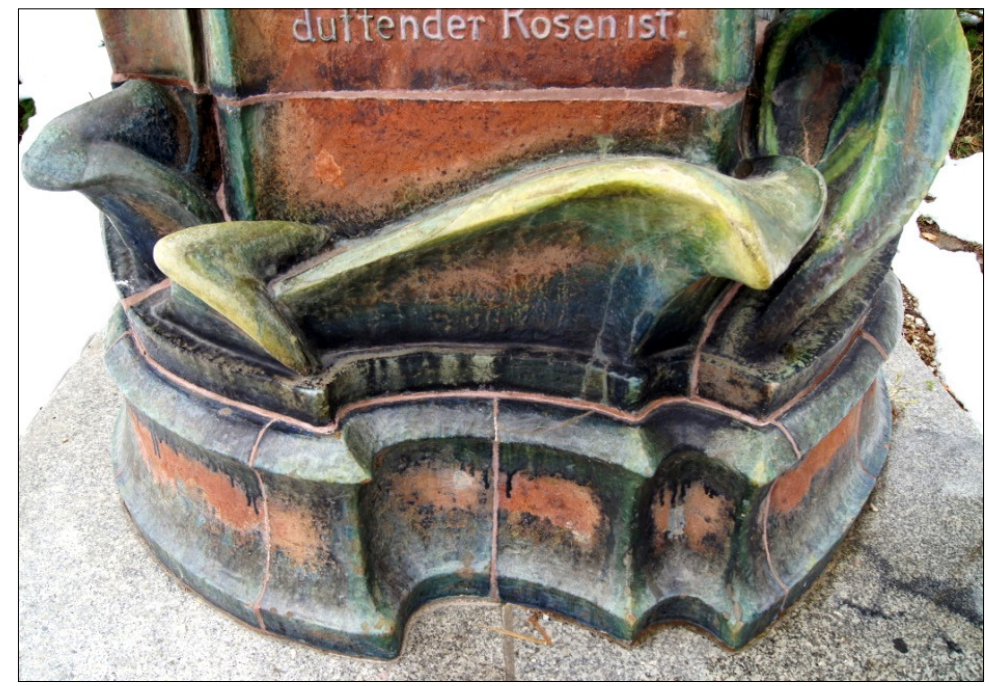

[361]

Fot. 14. Dolna partia nagrobka; stan obecny. Fot. A. Gul.

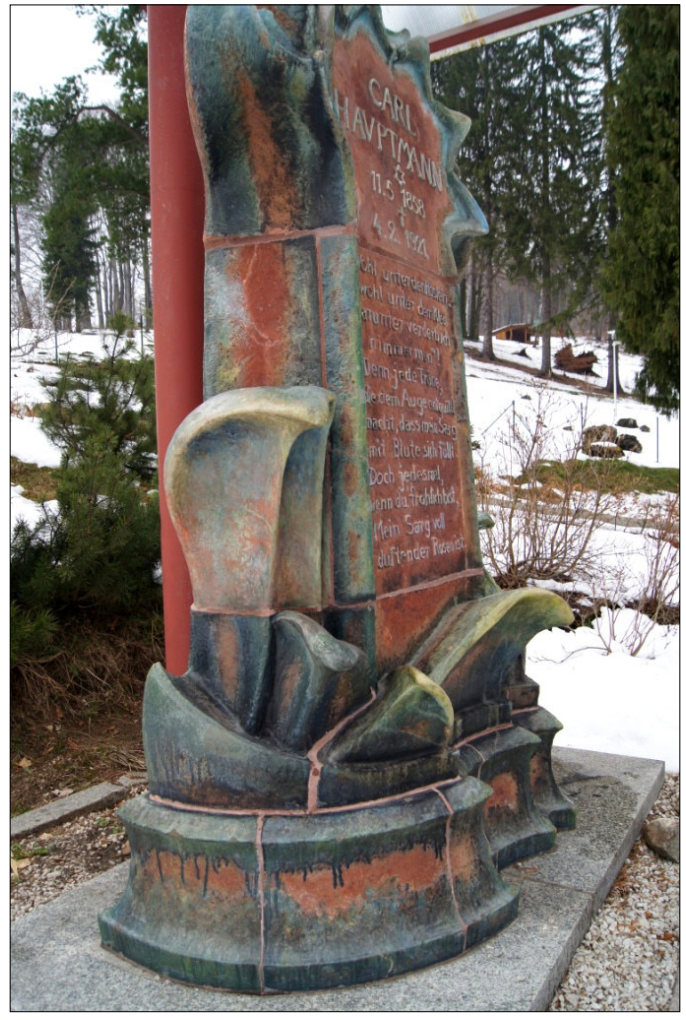

Fot. 15. Bok lewy nagrobka; stan obecny. Fot. A. Gul 


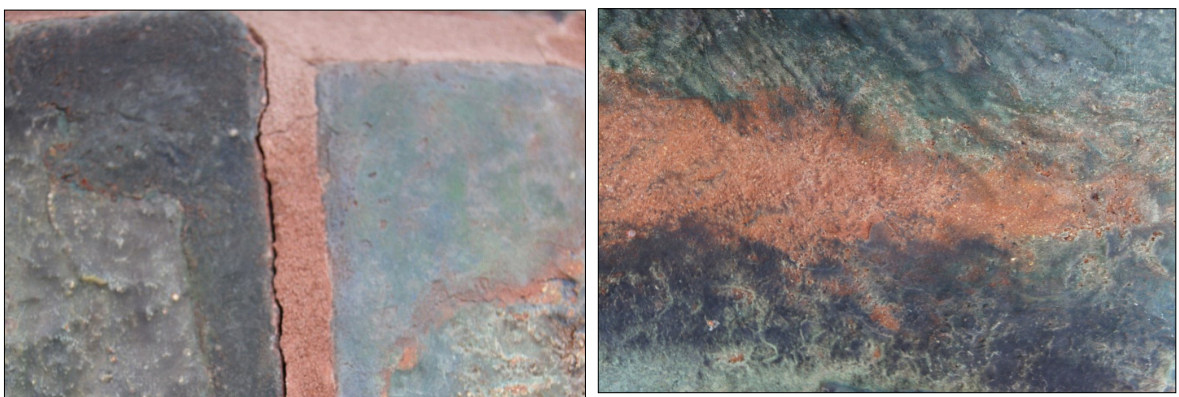

Fot. 16-19. Zbliżenia lica nagrobka Carla Hauptmanna; stan obecny. Fot. A. Gul
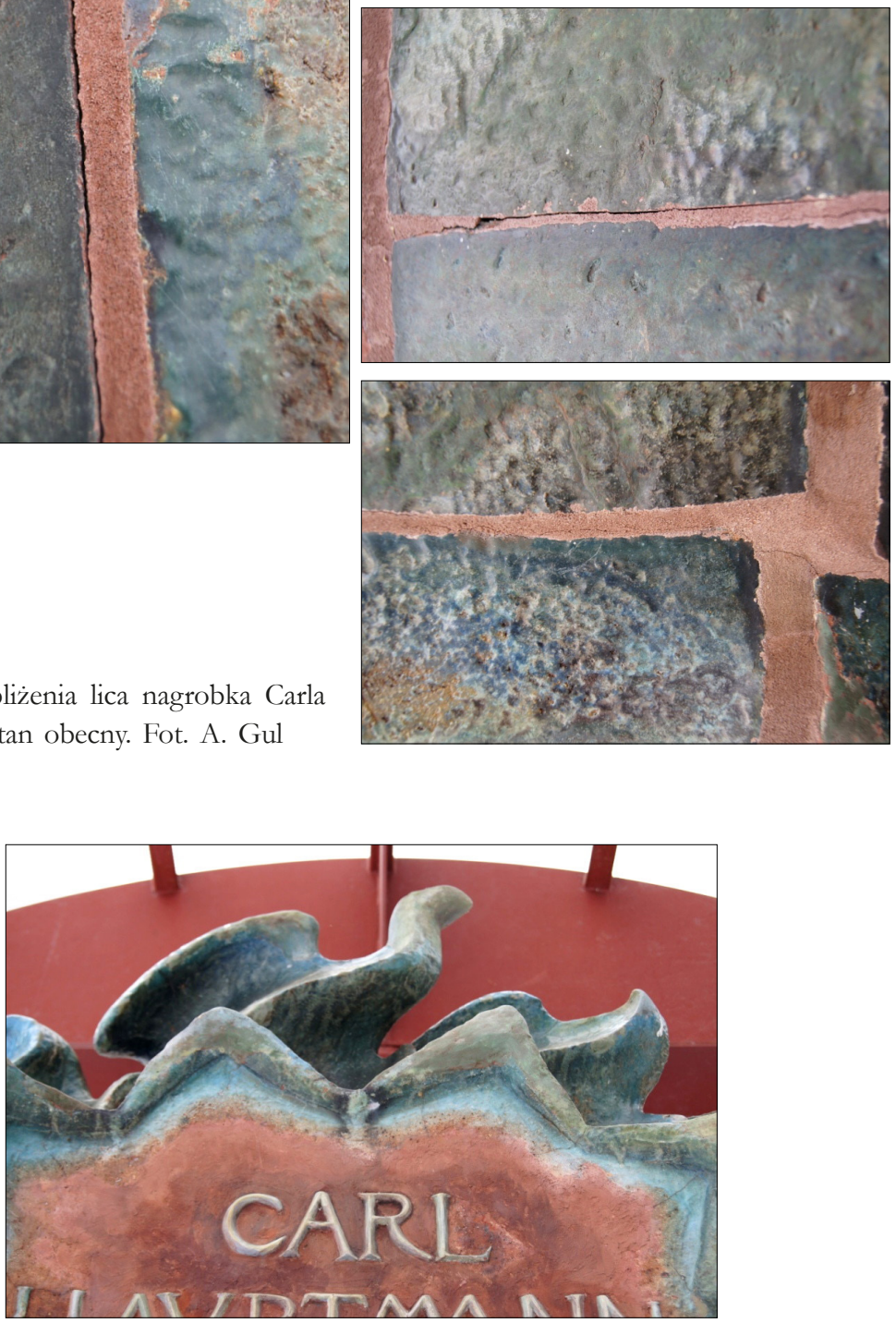

Fot. 20. Fragment zwieńczenia nagrobka; stan obecny. Fot. A. Gul 